\section{Policy Issues}

1. Why did Canada have the slowest record with respect to processing time for unaccompanied minors?

2. Who should be responsible for the transportation loan?

- The minors were not of legal age to contract for a debt.

- The federal government was unwilling; the permission of the Treasury Board to waive outstanding loans was denied in April of 1981.

- The NGOs in Quebec undertook to reimburse the federal government, but they assigned the costs to the sponsors.

- In Ontario, the sponsors signed an indemnity agreement; there was a question of whether one could indemnify a loan where the primary lender was a minor and where there was no means of legally enforcing the primary responsibility of the minor. In any case, it was very unlikely that the federal government would come after any private sponsor, particularly in cases of breakdown.

- The loans were in the minor's name, though in fact many did not sign the agreement. The minors could not be held legally responsible because of the situation under which they signed the agreement.

3. Was the medical survey necessary?

- The hepatitis B checks were eliminated in November of 1980; not one child was rejected by a sponsor because of suspected hepatitis $B$.

4. Should group homes and independent living arrangements be used as well as foster homes?

5. To what degree was Ontario's concern to make sure that it was not a party to the arrangements and would not become financially liable for the unaccompanied minors, since it was a volunteer responsibility, a hindrance to the intake of larger numbers of unaccompanied minors envisioned in the original project. In other words, did the efforts of the provincial government to protect itself from any financial responsibility interfere with the purported Ontario goal of reinforcing the voluntary sector?

6. Who should take care of the home studies, the orientation of sponsors, counselling for sponsors and follow-up; the NGOs or provincial governments?

\section{Causes of Breakdown}

1. Unaccompanied minor status was used as a stepping stone to come to Canada and seek reunification with relatives.

2. There are age discrepancies; that is, there is a difference between the actual and the reported age so that an 18-yearold arrives as a purported 15- or 16year-old.

3. Language barriers and inadequate interpretation services.

4. A mismatch of minors with the wishes of foster families.

5. The different expectations of sponsors and those of the minors concern- ing respective commitments, roles, conduct, etc. That is, who is right, the sponsor who wants the child to learn English or French for the long term, or the very young adult who is subject to pressure at age 15, and feels the responsibility to work, send funds home, help the rest of his or her family escape from Southeast Asia?

6. There is a lack of a detailed description on the background of minors.

7. The different types of family authority structures in Canada and Indochina, for example are maternal authority in Quebec contrasted with the paternal authority dominant in Southeast Asia.

\section{Processing Time*}

\begin{tabular}{l|c|c|}
\hline Country & Time & Conditions \\
\hline Austria & immediate & $?$ \\
\hline Belgium & $?$ & final and unqualified \\
\hline Canada & 2 weeks & conditional on medical ${ }^{* *}$ \\
\hline France & $1-2$ days & final and unqualified \\
\hline Italy & immediate & $?$ \\
\hline Sweden & 1 week & final and unqualified \\
\hline Switzerland & immediate & final and unqualified \\
\hline U.S.A. & $1-5$ days & $?$ \\
\hline
\end{tabular}

*UNHCR Report: July 1980

${ }^{* *}$ This process is speeded up in exceptional cases. Informed on a Friday about a young girl raped in a refugee camp, Canada organized the home study over the weekend and the post was instructed on Monday to send the girl immediately. 


\section{Legal Responsibility for The Unaccompanied Minors}

\section{Possibilities}

1.

2.

3.

4.

5.

$$
\begin{array}{r}
\text { the state - federal } \\
\text { - provincial }
\end{array}
$$

him/herself

the parents

the foster parents

non-governmental sponsoring agency unaccompanied minor

Is guardianship necessary?

Prior to the Children's Reform Act (1982) in Ontario, persons under the age of 18 defined as minors had a limited capacity to act for themselves in property or contractual matters, marriage or consent to medical treatment. Married and self-supporting minors as well as those nearing the age of majority had greater independence. The two key issues with respect to unaccompanied minors are education and medical consent.

The Education Act assigns responsibility to "any person who has received into his home another person's child who is of compulsory school age and is resident with him or in his care or legal custody." Thus, foster parents have a duty to send the unaccompanied minor to school. However, foster parents may not have the right to do so without payment of the non-resident fee unless they are also legal guardians who reside in the educational district or pay taxes in the school division. The Children's Law Reform Amendment Act provided a complementary amendment to the Education Act by defining a guardian, for fee purposes, as "a person who has lawful custody of a child," enabling anyone with a custody order and not full guardianship to be exempted from fees. (The Children's Law Reform Amendment Act was introduced in 1982; and although there was an issue about education fees there is no longer one.)

With respect to medical treatment, a minor capable of appreciating the nature and consequences of the proposed treatment (usually when one is aged 16 or 17), can give valid consent. A doctor would almost certainly require the consent of an adult with that responsibility for all other minors, and sometimes even for 16- to 17-year-olds. Further, The Public Hospital Act in Ontario requires the written consent of a responsible adult for hospitalization.

The latter issue was apparently resolved with the amendment of Part Three of the Children's Law Reform Act of 1982 in recognizing the child's views and preferences and the right of the child of 16 or 17 to withdraw from parental control and in general to speak and act alone. Thus, a 16- or 17-year-old would have the right to chose or refuse needed treatment, and, in fact, this might extend to any minor deemed to have sufficient knowledge and understanding to make a reasoned decision.

The issues of responsibility for education and medical treatment, particularly in cases of older unaccompanied minors, seem to have been overcome if the last several years by amendments to Ontario law. 